\title{
At the Margins of Empire: Feminist-Nationalist Configurations of Burmese Society in the Hindi Public (1917-1920)
}

\section{SHOBNA NIJHAWAN}

Embedded in early twentieth-century discourses on modernity, feminism, and nationalism, and written for the newly emerging woman reader, Rameshwari Nehru's Hindi account of Burmese women was an experiment in ethnographic writing. Along with the speeches she delivered in Burma (all reprinted in the Hindi women's periodical Stri Darpan), she also used the ethnography to call for the social and political mobilization of Burmese and Indian women. Nehru revisited the relationship between India and Burma in the gendered and elite terms of Indian (mostly Hindu) nationalism and social feminism. In describing a supposed intact social structure found in Burma, her motive was to portray a woman subject that was not modeled on prevalent conceptions of "the Western woman," but that originated in the neighborhood of the colonial present. In the process, as this paper argues, Nehru appropriated colonial discourses on Indian and Burmese womanhood, while she also absorbed Burma into her vision of Indian nationhood and imagined sisterhood.

$I^{\mathrm{N}}$ 1920, Rameshwari Nehru (1886-1966), a Hindi writer, editor, and political activist, published an ethnographic account of Burmese women in the Hindi women's periodical Stri Darpan (Women's Mirror, 1909-28). She, along with other women from the politically influential Nehru family, had pioneered the dissemination of feminist-nationalist thought in the Hindi public sphere. In the process, she had developed an understanding of feminism and feminist intervention in nationalist politics that was relatively new to the early twentieth century: alongside women's domestic-turned-nationalist responsibilities as wives, mothers, and homemakers, she placed emphasis on the political mobilization of women. As early as 1909, Rameshwari Nehru had established a local women's organization in Allahabad, the Prayag Mahila Samiti, and launched the Hindi women's periodical Stri Darpan, both with the objective to promote social liberation and political emancipation of what was, at first, a reasonable number of North Indian women. Shortly thereafter, she was invited to Burma to share the experiences of her mobilization efforts with a newly emerging 
middle class in Rangoon. In addition to her three public speeches delivered in Rangoon to women's organizations (Nehru 1917a, 1917b, 1917c), one of which was an Indian women's organization, ${ }^{1}$ she published two essays about Burma that were ethnographic in nature (Nehru 1920a, 1920b). These essays are informative with regard to their theme, namely Burmese culture and tradition, marriage practices in particular, as well as the status of women. Furthermore, they offer the rarely encountered micro-perspective of not only a colonial neighbor of Burma, but also a woman observer.

As I argue in the following, Rameshwari Nehru, in her desire to mobilize women in India and Burma, casually appropriated colonial discourses on Indian and Burmese womanhood, while at the same time revisiting the relationship between India and Burma in the gendered and elitist terms of Indian nationalism and social feminism. She presented herself with "maternal imperialist" airs and graces: ${ }^{2}$ arriving in Rangoon in 1917 to facilitate the social and political mobilization of women on local and national platforms, Nehru acted as the helpmate of an emerging Burmese middle class. Back in Allahabad, where she would compose her ethnographic accounts, she sought to include Burma in her vision of Indian nationalism and feminism that focused on the Indian woman. This move may be read as a feature of the subimperial relationship between India and Burma. ${ }^{3}$ Three assumptions of hers, however, complicate such a move: (1) Nehru projected Burmese society and culture, embodied through women, as a model for the Indian nation. (2) She did so without acknowledging the possibility for a Burmese nation. (3) Her ultimate goal was to galvanize Burmese and Indian women into political action. To communicate her messages to the readers of her periodical, she not only made use of a new genre in Hindi literature, the ethnography, but also drew on methods that have been used to describe imperial feminist aspirations of the same time period.

Throughout the ethnography, Nehru related her experiences in Burma to the lives and anticipated interests of the middle-class readers of her women's periodical. She paid much attention to her descriptions of the outer appearance of women in Burma, from clothing to hairstyles and the jewelry they typically wore, as well as their prevalent social activities and participation at religious

\footnotetext{
${ }^{1}$ This Indian women's organization in Rangoon is described as dysfunctional because of its irregular meetings and decreasing membership.

${ }^{2}$ Barbara Ramusack, from whom I borrow this term, has used it to describe five British women activists in India. These women had traveled to India as "cultural missionaries who preached the gospel of women's uplift based on models evolved in Britain, maternal imperialists who wanted to socialize immature daughters to their adult rights and responsibilities, or feminist allies whose effectiveness depended on their own personalities and skills, the institutional and personal alliances they formed, and the state of the women's movement in India when they were active" (Ramusack 1990, 310). ${ }^{3}$ Burma was annexed by the British in three consecutive wars $(1826,1852,1885)$ and amalgamated into the British Indian Empire as a British Indian Province. British India's subimperialism also manifests in the colony's modeling function for colonies in Africa and Egypt (Ballantyne 2003, 114-15; Metcalf 2008).
} 
functions and other festivals. Based on her observations, she concluded that Burmese women frequented the public sphere as respectable women. In describing various rites of passages in Burma, Nehru devoted much space to reflect upon what she saw as the degraded customs of India. The birth of every child, for example, was celebrated in Burma, unlike in India, where the birth of a girl was associated with expenditure and considered less auspicious than the birth of a boy. Childbirth rituals (dharmik rasm) were simple and modest in Burma, unlike the exuberant rites of passage (dharmik sanskar) in Indian (i.e., Hindu) rites. The same held true for marriage ceremonies. Equating Hindu with Indian customs as well as subsuming Buddhist practices under the umbrella of Hinduism, she repeatedly condemned supposedly degenerated, distorted, and corrupted religious practices (dharmik kriya) in India and extolled the virtues of "true" and "pure" dharma as practiced in Burma. She admired that social taboos in elite and middle-class Hindu India, such as divorce and the remarriage of widows, were not prevalent in contemporary Burma. Furthermore, she had not encountered cases of child marriage, female infanticide, exorbitant dowry demands, and polygamy during her travels (Nehru 1920a, 1920b).

Nehru's descriptions were at once analytical and comparative, aimed at uncovering "the secret" (rahasya) of women's independence in Burma and at better understanding the causes for social backwardness in India. She was particularly critical about Indian customs and habits that could not be explained with principles of modern reasoning, the use and application of which she was quite familiar with (Chakrabarty 2000, 124). ${ }^{4}$ In analyzing the customs and traditions of Burmese society in the gendered terms of Indian nationalism, Nehru also proposed an idea of sisterhood across imagined national borders. This sisterhood was marked by cultural affinity and appropriation as well as the shared experience of colonization. As I show through a close reading of her Hindi publications on Burma, Nehru described and assessed her subject matter with a heteronormative, upper-caste, Hindu nationalism in mind. This would rightfully lead to an inquiry regarding the degree to which Nehru may have constructed her portrayal of sisterhood in Burma: she readily appropriated Orientalist and other colonial writings, she drew on Indian and Burmese nationalist accounts that described the supposed high status of Burmese women, and she also relied on her own observations as a privileged observer and traveler to Burma. Her experience and knowledge was then disseminated through a relatively new genre of the early twentieth century, the woman-edited women's periodical. Nehru did not, however, acknowledge discourses of the Burmese vernacular press, which

${ }^{4}$ Chakrabarty (2000) has used this division to argue that for social reformers such as Raja Ram Mohan Roy the emphasis on reason provided an escape from "the blindfold of custom" and habit. It did not, however, replace all that was considered pre-modern. In Rameshwari Nehru's writing, reason is not always projected as antagonistic to something positioned as "unreason" or "irrationalism." Rather, reason is presented as a generally accepted and promoted mode of thinking that did not foreclose, but modified, tradition. 
hardly described an intact Burmese society and was instead raising awareness of potential threats thereto posed by waves of Western, Indian, and Chinese immigration. Her accounts did not mention the disintegration of traditional Burmese social structures as described in the Burmese vernacular press. Instead, her writing reflected an orientation toward Burmese women and culture that was ensconced within and nuanced by a Hindu nationalist discourse, a discourse that elite Indian women in the Hindi public also had their hand in shaping.

In this paper, I wish to investigate the interconnections of colonial ethnography, Indian nationalism as performed by elite women, and discourses on womanhood from the point of view of a woman writer and editor who had successfully claimed a voice in the Hindi public sphere. I investigate the manner in which and the purposes for which Rameshwari Nehru duplicated an Indian nationalist and imperial feminist script that did not take into account a Burmese society in transition. She descanted on the social and cultural organization of Burmese society, but she papered over the differences between Indian and Burmese religious organization and identity formation when they did not suit her primary aim, which was oriented toward the mobilization of Indian women to reform "fallen practices" in Indian society and to find a political voice. Still, she acknowledged that the social realities, both in India and Burma, had strengths and flaws: while the majority of Indian women lacked social and political awareness despite the reasonable number of leading female political and literary activists, Burma fell short of pioneers who could work towards women's political awakening, even though the ordinary Burmese woman was supposedly not as needy as her Indian counterpart.

\section{“A World of Difference”-In the Neighborhood of the Colonial Present}

At Anand Bhavan, the residence of the politically influential Nehru family in Allahabad, where Rameshwari Nehru came to live in 1902 after her marriage to Brijlal Nehru, ${ }^{5}$ she watched Indian nationalist politics unfold in a time period marked by increasing critical investigations of British colonial rule. This criticism was being articulated by the new generation of politicians, successors of the moderate founding members of India's first nationally recognized political party, the Indian National Congress (established in 1885). They distinguished themselves from their predecessors by seeking to mobilize larger sections of society, including women.

Rameshwari Nehru devoted much of her effort to demonstrating the ability of Indians for governance. In doing so, she focused on the status and position of women and for that purpose addressed women explicitly within her endeavor. As founding editor of the women's periodical Stri Darpan, she created her very own

${ }^{5}$ Brijlal Nehru was a nephew of Motilal Nehru and a cousin of Jawaharlal Nehru. 
interventions to explore women's future roles as citizen-subjects of a yet imagined nation. As an activist, she delivered speeches to build social reformist, educational, and women's organizations upon which could be hinged the political demand for self-government. Rameshwari Nehru also embarked on a political career in the late 1920s: she was to become a member of the Age of Consent Committee (1926-27), the women's representative of the Round Table Conference in London (1930), and a participant at the League of Nations in Geneva (1931) (Paliwal 1986). She undoubtedly believed that it was the responsibility of educated Indian women to articulate social feminist demands on behalf of a larger community of less-privileged women. Considering her advocacy of this position from the 1910s onwards, she could indeed be called a pioneer of women's mobilization, seeking to form a collective social and political identity for women that even transcended national borders. ${ }^{6}$ How did Burma tie into her project?

Burma, at that time already a province of British India, drew Rameshwari Nehru's interest during a period of heightened social awakening (jagaran) and attempts at political organizing: the first organizations of national character emerged in the early twentieth century (Aung San Suu Kyi 1990, 34; Maung 1980); English education was on the rise in cities; and the vernacular printing press shaped public opinion and featured, among other things, a diversity of representations of women (Ikeya 2008, 1282). Nehru, however, gathered her information not from the Burmese press, but - apart from her own travels in Burmafrom an image of Burma as it had been produced by nineteenth- and early twentieth-century Orientalists, missionaries, and colonial administrators. She also drew on Indian nationalist accounts of Burma. Their common denominator was the description of Burmese women's economic independence and social emancipation. To Nehru (1920a, 77) also, "the secret" of a woman's independence was that she was gainfully employed: "who else could be called independent if not women who perform the same occupations as men and as a result don't have to reach out to them for maintenance allowances?" Despite their supposed economic independence, the social and political spheres were yet to be made accessible to the majority of Burmese women, and Nehru considered the process of opening these sectors to female participation a special responsibility of hers. She also highlighted the supposedly advanced status of women in Burma as a sign of civilization that warranted political emancipation and independence from colonial rule. Here, her mode of argumentation resembled that of (male) Indian social reformers and nationalists who questioned the validity of the British civilizing mission. The annexation of Burma, they reasoned, was proof that even an evidently intact society was not granted the right to rule

\footnotetext{
${ }^{6}$ Mrinalini Sinha $(2006,10)$ has highlighted the formation and articulation of women's collective political identity as a major political achievement of the late 1920s.
} 
(Ikeya 2006, 11). ${ }^{7}$ Nehru twisted this argument so that it would facilitate the imposition of a feminist reading for both Indian and Burmese nationalism: intact social structures and emancipated women were a precondition for a country's political independence.

The production of knowledge about Burma and the representations of Burmese women in particular have continuously been marked by cultural stereotyping. Chie Ikeya $(2006,1)$ notes that, historically, "the notion of the 'traditional' high status of women in Southeast Asia has been foundational to paradigmatic understandings of the region as a distinct geopolitical and cultural entity separate from the rest of Asia (i.e. South and East Asia) yet part of the greater East." What is often termed as "tradition" in that respect "is a product of the multivalent representational practice by colonizing and colonized women and men in unequal relations of power who coauthored essentially and powerfully gendered discourses of colonialism, modernization, and nationalism" (1). Nehru fits into the category of the colonized woman. She belonged to a colonial elite that assessed women's social, legal, and economic conditions and produced writings on Burmese womanhood. The status of Indian women, Nehru said, paled in comparison to that of their Burmese counterparts, who resided in a society in which gender was supposedly embedded in a faultless social and cultural system. Nehru described this in minute detail. According to her, Burmese women were of high status and enjoyed complete independence as well as proprietary rights equal to those possessed by men. She asserted that "from birth to death the women of Burma enjoy equal rights" (Nehru 1920a, 80). In comparison, women in India (elite and upper middle-class women exempt) were worn out and lacked enthusiasm for life. They were unable to even recognize their oppression by men because they were being systematically kept in a state of ignorance: "Like a slave or servant her duty is limited to cooking, working on the grindstone and washing the dishes. She has neither the desire to progress, nor the energy" (Nehru 1917a, 4).

Nehru was particularly enthusiastic about the possibility of providing her account of customs and traditions of Burmese society with a special emphasis on the positioning (in terms of geography and class status) of women as subjects of a neighboring non-Western country: "An increasing number of knowledgeable Europeans would agree that women are nowhere as independent as they are here, in Burma. . . . I am particularly happy that the country that first granted women independence and equality lies in the Eastern hemisphere and is the neighbor of our Bharat. In India, women will also be independent one day.

${ }^{7}$ Bal Gangadhar Tilak, for example, concluded from his visit to Burma in 1899: "Some European writers have sought to advise us to bring about social reform as a preparation for political reform. But it is human nature that this piece of precept should stand suspect till we see with our own eyes what kind of political reform is given to Burma which is socially in a position to deserve it" (quoted in Aung San Suu Kyi 1990, 21). 
But currently a comparison of the women's communities in India and Burma displays two different worlds" (Nehru 1920a, 70).

In her accounts, Nehru reproduced parts of the colonial narrative on the supposedly traditional high status of Burmese women and juxtaposed it to the allegedly fallen position of Indian women. With respect to the urban Burmese public, however, we encounter glaring omissions: at no point did she mention that the supposed ideal social system in Burma was in flux. There was no reference to the woman question as debated in the Burmese public, such as the controversies over changing fashion trends; anxieties surrounding marriages of Burmese women to Indian, Chinese, and British men; and the nature of political mobilization against this supposed decline of tradition (Aung San Suu Kyi 1990, 49; Ikeya 2006, 2008).

Despite her detailed descriptions of Burmese marriage customs, Nehru at no point mentioned the prevailing critique of the loss of Burmese women's spousal rights to Indian men as a consequence of inter-marriages. Instead, she applauded the right of Burmese women to choose their own partners. Parental consent was desirable, but not mandatory, she held, and she readily used such examples of apparent empowerment to support her agenda of redefining acceptable marriage practices in India (Nehru 1920a, 73). ${ }^{8}$ While debates concerning inter-marriage in the Burmese press peaked in the 1930s (Ikeya 2006, 14-22), one decade after Nehru wrote her account, political mobilization against this supposed decline of tradition was first witnessed in the early 1920s. The initial protests were assembled by the then newly founded Burmese nationalist women's organization, Wunthanu Konmaryi Athin (16). The formation of this elite organization in 1919 was neither mentioned in the ethnography nor in sections of Stri Darpan that covered news about women's organizations around the world. Why was Nehru omitting the changing representations of women in the Burmese press as well as the emergence of women in Burmese nationalist organizations? Her apprehension in intervening in Burmese vernacular debates, especially those launched by Burmese women, may be a reaction to a criticism against inter-marriages raised by the Wunthanu Konmaryi Athin, according to which Burmese women had effectively forfeited their rights of divorce and inheritance to Indian (Hindu and Muslim) men (16-18). Nehru did not shy away from criticizing men and patriarchal structures in her writing, and as editor she persistently supported a diversity of viewpoints from women and men on the linked topics of patriarchy and women's domestic roles. In this case, however, Nehru needed an image of Burmese women as a pristine and progressive model for the women in India. Hers was a narrative of hope for India, not of decline in Burma. In portraying ideal social realities in Burma, she intended to lead

${ }^{8}$ Nehru promoted the view that marriage did not have to be the sole purpose in a woman's life. Social service and delaying marriage, or not marrying at all, were other valid options according to her (Nijhawan 2012a, 161-62). 
Indian women onto a path that was progressive and traditional rather than overtly Westernized. Intervening in the Burmese public's protest regarding the loss of Burmese women's rights in inter-marriage was not advantageous to her cause.

The description of intact social structures in the colonial neighborhood was intended as an incentive for the readers of Stri Darpan to instigate change in their own families and localities. In addition, Indian women could be of avail to Burma: Nehru imagined a community of upper-class Indian and Burmese women who one day would mobilize all women to articulate the demand for political emancipation. This vision is particularly noticeable in the speeches she delivered in Burma, in which she called upon Burmese and Indian women to unite and spread awareness of women's fallen position: "Sisters, it is absolutely necessary that we recognize our state in the world, in our country and in society, before we can set out to progress. We need to understand women's social position" (Nehru 1917a, 4). The emancipation of women that would accompany social reforms, in particular higher education, was conceptualized as a precondition to political independence, not a logical consequence thereof (Nehru 1917c, 311). This was also the underlying agenda of Stri Darpan.

Distancing herself from representations of women as religious-nationalist icons, mostly modeled after women of a projected golden Vedic past, Nehru emphasized the lives of "real" women, in this case Burmese neighbors, with whom the readers were also more likely to relate than with Western women. ${ }^{9}$ Burmese women were presented as simultaneously traditional and potentially more progressive, while there was also emphasis placed on the fact that they were not Western. An ethnographic account was particularly useful, as it allowed Nehru to narrate what she had actually seen and thus go beyond other genres of fiction and the essay. As a consequence of being raised in an environment that promoted gender equality, she concluded, Burmese women were more confident and aware of their familial and social responsibilities. At home, they were true companions to their husbands, and the demonstration of their unconditional devotion was not limited to domestic servility. Furthermore, Burmese women were intellectually on par with their husbands: "The Burmese wife is a true friend and companion of her husband. Her devotion towards him (pativrat dharma) is not limited to washing his feet or comforting him with cool air; she is on his side in all life-battles, she bears the difficulties of life just the way he does and she fills his life with joy and happiness" (Nehru 1920a, 77).

\footnotetext{
${ }^{9}$ In order to promote women's education, Stri Darpan also provided information about the lives of Western women. Some articles were translations from Anglo-Indian periodicals while others stemmed from personal encounters with Western women in India and abroad. Their aim was to destigmatize and demythologize any negative perceptions about Western women's alleged sexual liberty and self-indulgence. But Western women seldom acted as role models to Indian women. Of model character were the women of Japan, "the most progressive country in Asia," as Rameshwari Nehru described the country (Nehru 1917c, 313).
} 
Burmese women frequented the religious public in a dignified way and paid much attention to maintaining modest behavior and a cultivated outward appearance. ${ }^{10}$ This assessment stemmed from a religious celebration Nehru had attended, at which she was struck by the festive attire of women. "I asked my husband whether these were rich and privileged women. He responded that ordinary women lived according to these high standards. . . If one even attempted to find a ragged, ill-groomed woman one would not succeed. . . I compared this splendor to the gatherings at festivals and in temples along the riverbanks of our Ganges. It was a world of difference" (Nehru 1920a, 70). ${ }^{11}$ Other public spaces were equally frequented by Burmese women who, for example, partook in market relations as both consumers and sellers: "Women sell dry fruit, vegetables and other small items in their shops. . . All are properly clad. Many wear golden bracelets around their arms and diamonds in their ears" (75). Apart from the marketplace, Nehru also encountered Burmese women and their families at dances, horse races, or gambling events targeting the upwardly mobile urban middle class and elite. The public was projected as a safe place in which no woman (Rameshwari Nehru included) was at risk of losing her respectability.

Nehru (1920a, 76) was very clear about the way Burmese women perceived themselves: "They do not consider themselves less worthy than anyone else, regardless of gender and caste $(j a t i)$. This attitude is visible in everything they say." As the essays in Stri Darpan demonstrated, Indian women were still far from this self-confidence, which was primarily due to their lack of education. Such was not the case in Burma, where women, according to Nehru's (1917c, 310) numbers, had received basic education in monasteries at a young age. The degree to which official Burmese figures corresponded to Nehru's numbers cannot be verified. Colonial sources, however, suggest low numbers of women's and girls' education in religious institutions while they also highlight the rise of women's education in government institutions (Ikeya 2006, 66; Lwyn 1994, 65). Nehru was not very reflective about the social sanctions around the entry into such educational spaces. She instead reproduced a modernist narrative of improvement through widespread education.

\section{"Mission Burma": Rescripting Feminist Reformism}

Nehru's fascination with Burmese culture and the religious (dharmik) practices set the tone for her ethnographic accounts. But, as I have already indicated,

\footnotetext{
${ }^{10}$ Fashion was the topic of a vibrant debate in the Burmese popular press of the 1930s, but as early as 1917, cartoons and articles in dailies condemned Western clothing as unbefitting for Burmese women and morally precarious (Ikeya 2008, 1288).

${ }^{11}$ It needs to be remembered that women's economic emancipation also came with women's subordination to men in religious, ritualistic, and ceremonial contexts, as "the worldly sphere of commerce, profit-seeking and monetary affairs was deemed spiritually polluting" (Ikeya 2006, 20).
} 
her fascination for the cultural other was undergirded by the intention to establish women's organizations and to further education in Burma. To meet these ends, she highlighted the pioneering role of Indian upper middle-class and elite women who frequented the North Indian public sphere and who would be instrumental in equipping Burmese women with the necessary tools for social and political mobilization. During her travels in Burma, Nehru observed that higher education amongst women was not as widespread as it was in India. Citing statistics from the Gazetteers of Upper Burma and the Shan State of 1911, she also noted that the English language was barely known by the Burmese population, rural and urban alike. Nehru had furthermore never heard the name of any Burmese woman writer or editor and it is out of this understanding that she argued for the establishment of social organizations in Burma.

By now it will have become obvious that Nehru's mission in Burma had complex motives steeped in sometimes contradictory ideologies. She had been invited to support the establishment of women's organizations in Burma. ${ }^{12}$ Stepping into this role at a time when the British Margaret Cousins and the Irish Annie Besant were collaborating with Indian women to establish national women's organizations in India (Forbes 1998, 73, 79), ${ }^{13}$ Nehru's agenda did not foster a sisterhood between Britain and India. Instead, she turned from the Hindi heartland towards the British Empire's Southeast Asian colonies when calling for solidarity amongst colonized women. To a certain extent, her creation of an Indo-Burmese feminist reformist program parallels that of Western actors involved in discourses on Indian womanhood. Arguably, many British feminists of the nineteenth century appropriated the discourse on Indian women for their own means: Josephine Butler, Millicent Fawcett, Flora Annie Steel, and others campaigning on behalf of Indian women were doing so to strengthen feminist agendas in their home countries (Burton 1990; Paxton 1990). Nehru certainly had the readers of her women's periodical in India in mind when writing about Burmese women. But she was also reproducing colonial debates and inserting her voice into Orientalist and civilizing discourses of the time and thus effectively challenging male predominance inherent in these discourses. In this respect her account bears similarities to travel writings of British women. ${ }^{14}$ Based on such accounts, it has been argued that British women

\footnotetext{
${ }^{12}$ It is possible that Rameshwari Nehru had been recruited by the Indian National Congress to support the Burma Committee of the Indian National Congress. Her call for education would then be in line with the committee's involvement in funding the National Education Movement in Burma. This connection is not confirmed by my primary sources, but I thank Chie Ikeya for pointing out this possibility.

${ }^{13}$ Western feminists were also involved in the production of knowledge on Burma. In the 1930s, they referred to the egalitarian status of women in Burmese society when demanding the enfranchisement of women in Burma (Ikeya 2005-06).

${ }^{14}$ For travelogues, see Ghose $(1998,27,33)$.
} 
were not at all marginal to the Empire, but took part in creating (and dismantling) it (Chaudhuri and Strobel 1990, 290-91), while simultaneously British imperialism shaped the diverging ideologies of British feminists from Annie Besant to Flora Annie Steel (Paxton 1990, 335). The case of Rameshwari Nehru may be read as one in which an elitist nationalism that was also subimperial feminist in character manifested itself in the writing about the cultural "other."

Nehru's feminist thinking was embedded within Indian nationalist frameworks in which actors called for political emancipation and the creation of Indian subjects with citizen rights. But Nehru was a colonized woman, albeit a very privileged one, who had turned eastward for inspiration and knowledge. Her interactions with Burma are testimony to an alternative way of figuring women, in which feminist-nationalist ideology was shaped by a South-South encounter. Whereas women such as Mary Francis Billington in 1895, Flora Annie Steel in 1898, and Katherine Mayo in 1927, as well as various other women travelers in India, had produced negative stereotypes of Indian women and Indian society (Billington [1895] 1925; Ghose 1998; Paxton 1990; Sinha 2006), Nehru, to some extent equally mindful of subimperial intentions, was conspicuously nationalist when discussing Burmese customs. She did not reproduce unconditionally colonial discourses on Burma and India, but reshaped them by reading colonial sources in a way that would suit her agenda. She was also asserting her national, Hindu upper-caste, and upper-class identity in her assessment of the situation of women in both countries.

One example of her incorporation of Burmese religion and culture into her program for the Indian nation is in her usage of the term "dharma" (moral duty). While she discerned the gendered aspect of the term, the differences between Hindu and Buddhist customs remained unacknowledged. To Nehru, dharma was a universalist marker of Indian identity. She distinguished between "good dharma" (guided by reason) and "bad dharma" (guided by custom), but not between the Vedic-Brahmanic dharma used to justify stringent caste and gender roles and the dhamma found in the teachings of the Buddha. Nehru's Hindu-centered conception of Indianness did not allow for religious antagonism or critique of the Vedic-Brahmanic meaning of dharma (Gombrich 1988, 33). There is also a conspicuous silence surrounding Theravada Buddhism and how religion and religions in contact specifically shaped gender relations in Burma. So, while Burma acted as a social model for India, Burmese efforts to safeguard a national Burmese identity along with a distinct religious Buddhist identity were not accounted for by Rameshwari Nehru. This is surprising, especially since she was traveling in Burma at a time when representatives of the Burmese public had sent a delegation to Lord Montagu in protest of British colonial officials' disrespect towards religious practice. ${ }^{15}$

\footnotetext{
${ }^{15}$ The matter revolved around the refusal of officials to remove their shoes when entering sacred spaces (Bechert 1984, 150).
} 
Notwithstanding Nehru's appropriation of mainstream Hindu nationalist definitions of the term "dharma," she seemed genuinely interested in learning from Burmese women, and what she encountered decisively formed her feminist-nationalist mode of argumentation. Her account reads as an appraisal of the Indian situation and distinguishes itself from those of many Western feminists who participated in civilizing discourses in such a way that their writings about the status of women in India legitimized colonial rule (Burton 1990; Paxton 1990; Sinha 2006). There were also instances in which Western women displayed objectives that "straddle[d] the reforming imperialism of the late nineteenth century and the independence movement of the early twentieth" (Tuson $1995,6)$. Such a description has been applied to the anti-imperial activities of the Irish theosophist Annie Besant, who would embark on a political career in collaboration with Indian nationalists (6), and Mary Carpenter, who was involved in establishing women's educational institutions in India (Ghose 1998, 12), as well as Margaret Cousins, who transcended racial boundaries as she established national women's organizations in India (Ramusack 1990, 318). It is also true for Rameshwari Nehru, who, like Besant, Carpenter, and Cousins, interlinked reformist subimperialism with feminist reformism and nationalism. But her ethnography refrained from reproducing a narrative based on cultural superiority as it was often encountered in Western women's attempts to distinguish themselves from the colonial other. ${ }^{16}$ While certainly reproducing parts of the well-known colonial narrative on Western superiority, Nehru avoided venturing into evolutionist and primitivist discourses that constituted the framework through which nineteenth-century European discourse had often perceived the nonWestern world. Her primary goal was the empowerment of the colonized women of India and Burma, and for that she modified the Indian nationalist framework that was available to her by including Burma in her vision for women as well as glossing over the cultural differences when she deemed it necessary to create a narrative of unity. Furthermore, Nehru did not write in idioms of the "burden" in the way it was found in many Western women's narratives on colonized women (Burton 1994; Jayawardena 1995). She also did not revert to claims about a supposedly golden past in which women had been revered and respected by men. Instead, she highlighted the cultural affinities of Burmese and Indian customs in order to present her vision of change for India.

In the next section, I discuss the role of periodical literature in facilitating the emergence of new genres in Hindi literature, such as the ethnography. Nehru had chosen this genre to create a believable and enticing account about Burma and Burmese women for her Indian readership. ${ }^{17}$ At the same time, she stretched the boundaries of the genre in that she used it to reflect about her

\footnotetext{
${ }^{16}$ See for example the case studies in Burton (1990, 296-97).

${ }^{17}$ Dalmia $(1998,172)$ notes the ethnological approach in the Hindi prose narrative of 1870 , Devrani Jethani ki Kahani, in which the author Pandit Gauridatta insists that his descriptions of the
} 
experiences of organizing women with the ultimate purpose of mobilizing Indian and Burmese women. Certainly, Nehru's account can hardly be situated in the category of confessional field literature or experimental ethnography that Kamala Visweswaran (1994) identifies in her explorations of feminist ethnographers. However, it bears affinities to efforts to "build a believable world [that] the reader will accept as factual" (Visweswaran 1994, 1) ${ }^{18}$ and is therefore worth a closer investigation to better understand Nehru's feminist-nationalist agenda.

\section{Ethnographic Writing in the Hindi Women's Periodical}

In Hindi literature of the mid-nineteenth century, the periodical became the primary site where new literary genres in Hindi prose and poetry took shape (Dalmia 1997). Multi-authored periodicals allowed for diverse literary styles and modes of argumentation. Furthermore, a number of viewpoints pertaining to the same topic could be articulated within one editorial framework, provided the editors permitted such diversity. Such was the intention of several women's periodicals of the early twentieth century (Nijhawan 2012a): Hindi women's periodicals emerged at the historical conjuncture of changing mainstream discourse, when, among other things, calls for social reform were being rephrased in nationalist idioms. They not only were a source of information mostly (but not exclusively) for women and very often in women's own words, but also constituted a distinct literary genre that interacted with other literary genres at a crucial point for Indian nationalism: the forming of a national Hindi language and literary tradition. Correspondingly, the periodicals were subject to experimentation with new genres and revision of old ones. For elite and middle-class Hindu women, to whom the periodicals primarily catered, they became a medium to think in new idioms of feminism and nationalism and to communicate with a geographically dispersed female readership. What had once been written by predominately male social reformers and been termed proscriptive and "suitable" literature for middle-class women gained new meaning in writings by women of the early twentieth century. Nehru's two-part ethnography was embedded within the pages of her women's periodical Stri Darpan.

businesspeople in Meerut are true and that there is "not a hair's difference" between reality and his literal rendition. Nehru also makes such claims about the reliability of her account.

${ }^{18}$ Yet, the boundaries between fact and fiction remain fuzzy in ethnographies as well as fictional genres. Visweswaran $(1994,1)$ writes on this: "Yet even this distinction [between ethnography and fiction] breaks down if we consider that ethnography, like fiction, constructs existing or possible worlds, all the while retaining the idea of an alternate 'made' world. Ethnography, like fiction, no matter its pretense to present a self-contained narrative or cultural whole, remains incomplete and detached from the realms to which it points." 
Stri Darpan went beyond advocating education in domestic skills and proper conduct for women. Formatted to the size of a handy booklet, the Hindi monthly counted 1,000-2,000 subscribers. It contained several features, such as an editorial with extensive news coverage on topics pertaining to women and politics; book reviews; readers' letters; essays on social reform and nationalism centering on the woman question; a domestic advice section on healthy living, child rearing, and household management; scientific and moral essays; poetry; and a prose section with short stories, biographies, and serialized novels. Besides fostering a feeling of sisterhood, Stri Darpan's female editorial board appealed to women to recognize oppressive social and patriarchal structures and develop a sense of patriotism that would encourage them to participate in the nationalist movement not only from within the domestic sphere, but also through active involvement in the public sphere. They were asked to do so by tapping new arenas such as those in education, social organizing, and writing. The ethnography on Burmese women was part of editorial efforts to create a critically informed public, in which readers knew about Indian nationalist politics as they unfolded in their own localities and the British Empire, and also understood the significance of such information for the emergence of women as political subjects.

Nearly every issue of Stri Darpan in the late 1910s carried reports from (mostly women's) travels or study abroad, articles about the quotidian lives of women, and the social and political achievements of women's organizations in countries around the world. Such information was not solely gathered from the Western world: while women's writings and activism were certainly fed by news about women's social liberation and political emancipation from the British mainland and the United States, women's periodicals also carried news about women from within British India and the non-Western world, such as Japan, China, and Fiji. This diversity was essential to forging a pan-Asian identity of women. ${ }^{19}$

U Chit Hlaing $(2008,241)$, in his survey of anthropological communities involved in the production of knowledge about Burma in the nineteenth and twentieth centuries, lists an impressive number of publications. He also considers Burma's marginal position in British India. Whereas his focus is on Englishlanguage sources produced by scholars, travelers, and British officials, there is now also evidence of South-South information exchange in the vernacular. In Nehru's accounts, the parallels to anthropological work on Burma of that time period are engaging. Her descriptions bear resemblance to romanticized accounts of early British administrators in Burma, such as Fielding Hall. ${ }^{20}$

\footnotetext{
${ }^{19}$ See my work on the All Asian Women's Conference in Lahore (1931) as an example of women's networking on a pan-Asian platform (Nijhawan 2012b). A central feature at this conference was the idea of Asian identity and cultural unity.

${ }^{20}$ His writing is quoted in Aung San Suu Kyi $(1990,57)$.
} 
They also take after the writings of Indian social reformers and nationalists, such as Bal Gangadhar Tilak. Whether she had consulted articles on Burmese women published by women in late nineteenth-century British feminist periodicals cannot be determined. ${ }^{21}$ There is no doubt, however, that the sources available to her complemented her primary source of information, which was gathered from her travels. While the credentials of her husband and escort on her trips to Burma, Brijlal Nehru, are not provided to the readers of Stri Darpan, it cannot go unnoticed that this husband and wife pairing constituted privileged observers. Nehru chose the genre of ethnography rather than that of the traditional essay and thus employed a novel method of "writing about others" during a period in which ethnographies written for Western audiences flourished.

Other scholars have also discovered such supposedly inconspicuous travel genres written by women and have tapped these historical archives to analyze colonial and imperial society with new, innovative questions in mind (Chaudhuri 2008; Grewal 1996; Sen 1990). Nupur Chaudhuri (2008, 211), for example, discerns that the account of Krishnobhabini Das's travels in England, published in 1885 in a Bengali women's periodical, was not only a description of English society with an emphasis on the lives of British women; it was at the same time testimony of the author's vision of Bengali nationalism and feminism. While Das chose a comparative approach in which the (past) Vedic era and (present) Western modernity coalesced, Nehru focused on what she had encountered in the colonial present and interlinked this knowledge with colonial accounts of Burma. In this process, Indian and Burmese national markers coalesced as she conceptualized social and political reforms in anti-colonial and antipatriarchal terms. While she did not entirely breach the elitist framework, her relationship to Burmese women and her approach to knowledge production was not fraught with elements of a "colonizer-colonized" relationship, even though it was hierarchical to the degree I have outlined in the previous section.

As a method of scholarly research and writing, the genre of the ethnography is firmly established today and has found entry to a wide range of academic enterprises, including literary studies. Ethnography is based on an integration of fieldwork and its literal representation. In that way, the method and genre is committed to translating the intersubjective process of the anthropological encounter into accounts of the cultural other. The generic and literary conventions of narrating cultural encounters, however, originate from a broad field of ethnographic enterprises that are characterized by the "self-other" distinction. Writing about others, as these research endeavors suggest, not only is informative in scope but also becomes a way to reflect upon oneself as an individual, a social

${ }^{21}$ In 1868, for example, Mrs. Bayle Bernard published an article titled "The Burmese Woman" in The Englishwoman's Review. As Victorian and Edwardian women's periodicals also circulated in British colonies, it is not unlikely that Nehru had access to such English-language sources on Burma. 
group, or a nation. ${ }^{22}$ In this sense, Nehru's account is paradigmatic. At the time she wrote her account of Burmese women, ethnographic writing was strongly shaped by colonial interests in data gathering and categorizing the other. While anthropology as a discipline and the ethnography as a genre were not yet established institutions in the early twentieth century, European travelers and Orientalist scholars, among others, were encountering "the other" in remote places of the world, far away from their Western homelands. They provided the grounds from which new cultural understanding emerged.

Despite the "world of difference" that Nehru noted when comparing customs of India and Burma, the self-other distinction with which she was confronted was embedded within cultural and geographical proximity. The writing about "gendered objects of interest" was becoming popular in the late nineteenth century and featured, among other things, writings on Indian women by women in the West. Rameshwari Nehru's ethnographical account is not a straightforward attempt to disseminate knowledge about women of varying cultural and national belonging to the readers of her home country. She was writing about a lost Indian self that was still existent in Burma and that Indian society had to reclaim. At the same time, she also viewed herself as a privileged woman and a pioneering political activist who would lead both Indian and Burmese women towards the end of colonial rule.

By introducing the ethnography to the readers of her Hindi women's periodical, Nehru accommodated nationalist and feminist perspectives and aligned social with political concerns (Sinha 2006, 10) ${ }^{23}$ The way she understood ethnography made it possible for her to produce a type of knowledge based on personal experiences, including her conversations with Indians and Burmese as well as her participatory observations in public and private spheres. ${ }^{24}$ Her work clearly shows her knowledge of the genre of colonial ethnography in a period when Western anthropology was undergoing a shift from the comparative approach to the ethnographical method of participant observation (Buzard and Childers

\footnotetext{
${ }^{22}$ In recent years, there have been debates about the nature, context, and form of ethnography. Feminist scholars in particular have drawn attention to feminist endeavors to represent culture by including creative genres stemming from (women's) oral narratives (songs and stories). They also highlight the subjectivity and positionality of knowledge production as well as the complexities around the dissemination of knowledge (Visweswaran 1994). Nehru's account is also attentive to such questions. She for example articulated her positionality and uncertainties repeatedly, such as when looking for explanations of cultural artifacts, with phrases such as "I thought," "I asked my husband," or "as far as I know."

${ }^{23}$ I borrow this wording from Sinha (2006), who speaks of the social and political alignment in the context of women's organizing in the 1927-29 controversy over the publication of Katherine Mayo's account Mother India.

${ }^{24}$ She mentions that she stayed in Burma for three years; however, it is more likely that she traveled back and forth over a period of three years, since she attended to the needs of Stri Darpan from Allahabad.
} 
1999). Nehru reflected upon and was aware of her sources of information. ${ }^{25}$ She consistently referenced her information and inserted herself into the text in many instances. Her work may be qualified as part of what could be called an intermediary phase of colonial and modern ethnographical approaches to the subject matter. She drew from categories as they had been established in colonial ethnography delineating the ethnic diversity (bhinn jati) of Burma. In a nationalist move, she also emphasized that ethnic diversity was not antagonistic to national unity, thus projecting an image of Burma as a future nation: "The readers should not think that the differences are an obstacle to unity. None of these customs is less Burmese than another is" (Nehru 1920b, 125). This was the only instance in which Nehru acknowledged Burma's national identity as separate from that of Indians.

What was important, Nehru concluded, was to know about the practices of other people. "The world is large," she held, "and events of the day need to be made known to the common people" (Nehru 1920b, 130). This statement also underlay her editorial project: exposure to information that went beyond the readers' immediate surroundings and fields of activities would stimulate their critical thinking and political participation. Affinities with the Habermasian model are thus also found in early twentieth-century women's periodicals (Orsini 2002, 11). While the editorial of the inaugural issue of Stri Darpan still claimed to be oriented along the lines of social reforms and thus instructing women in domestic skills, it was the "uncensored flow of information" (Orsini $1999,148)$ in the two decades to follow that allowed for the emergence of a new awareness of women's nationalist responsibilities beyond the domestic realm.

\section{Conclusion}

The ethnographer and novelist Amitav Ghosh in his novel The Glass Palace (2001) has reread the history of Indian nationalism through the lens of colonial Burma. He chooses a cross-border perspective that is also from the margins of the British Indian Empire. Furthermore, he uses the biographies of female protagonists to embody the links between India and Burma. In this paper, I have also attempted to shed different light onto the history of Indian nationalism, by investigating an encounter of one individual Indian woman with Burmese society.

To Rameshwari Nehru, women offered a significant entry point and opportunity to scrutinize colonial knowledge for an emerging feminist-nationalist idiom. For her representation of Burmese women, she selectively used images

\footnotetext{
${ }^{25}$ Apart from the sources already mentioned, she had interviewed Burmese women and had had conversations with her husband and their barrister friends.
} 
culled from her own ethnographic experience as well as colonial and Orientalist writings to cast Burmese women socially as more advanced than Indian women, and thus a model for women's emancipation in India, and, at the same time, politically in need of a voice. Nehru's apparent motive was to portray a woman subject that was not modeled on the Western woman and that at the same time went beyond the well-known sacrificial and submissive notions of Indian womanhood. Rather than establishing a temporal bridge to the (Vedic) past, she focused on Burma as a country in spatial proximity. Her case study of exceptional gender relations was situated neither in the temporal past nor in geographical distance, but in relative proximity to home (the United Provinces). Furthermore, it could be recounted in cultural nationalist terms. The attributes of the cultural neighbor offered her readership imaginative possibilities in ways that were decisively different from those prescribed in the missionary language of social reform: a society did not have to be corrupted by "bad" practices such as child marriage, the wearing of excessive jewelry, female infanticide, and excessive dowry demands; women could frequent the public sphere as respectable women-Nehru had witnessed it all in Burma. Moreover, couching gender equity in terms of Burmese tradition and culture would likely not have been subject to attacks from those prejudiced against Western concepts of women's liberation.

Whether Nehru's publications, apart from her speeches, had any impact in Burma is unknown to me. At any rate, her ethnographic gaze at Burmese women also tells a story about a colonized woman's agency that may be uncovered when vernacular publications are considered that otherwise go unnoticed in colonial archives and libraries. Writing "human-scale studies of modes of thought and practices in colonial times" offers an exceptional perspective on the richness of local colonial histories and individual agents, which included women (Blackburn 2010 , xiv). As Anne Blackburn (2010, xiv) writes on the topic of micro-histories of the colonial world, "We need a number of such studies of colonial period southern Asia, focused on different historical moments and examining a variety of persons and networks." What made Rameshwari Nehru's project the driving force for women's mobilization was her nuanced Indian elite vision of nationalist feminism along with a degree of feminist imperialism, for which she constructed an image of a Burmese other to sustain a feminist agenda back in India. Her account also cascaded into a call to Indian women that gender relations were open to exploration and contest. The most emancipated women, she claimed, lived in Burma, and this, she reckoned, was not a subjective opinion, as colonial authorities and Indian nationalists agreed that such was the case.

By the 1920s, the Burmese press listed a pool of educated women who had ventured or were about to venture into the professions of medicine, education, journalism, and law (Ikeya 2008, 1296). Women's branches of nationalist organizations in Burma mushroomed in the 1920s and 30s, drawing a range of women from students to factory workers into the anti-colonial struggle (1293). These 
organizations were self-proclaimed nationalist, not feminist, organizations. But in focusing on how social change affected women negatively, Burmese women, like Indian women, assessed the state of their society in idioms of loss. This paper, however, has not concerned itself with Burmese women's agency. Rather, its focus was on the representation of Burmese women in a feminist-nationalist Hindi discourse. I showed that the feminist exchange taking place in Burma was part of Nehru's own larger Indian nationalist aspirations. For the establishment of women's organizations in Burma, India, as envisioned by Nehru, took on a patronizing function. Such ambiguity has been described by Thomas Metcalf $(2008,1)$ in the relationship of British India to other British colonies, where "the India of the Raj" took on a central role for the expansion of the British Empire. Nehru’s South-South framework highlights yet another such particular relay.

After her subsequent visits to Burma, Nehru attached importance to imparting the knowledge she had gained about the country to the readers of her periodical. After all, her larger project in India was to mobilize Indian women. The ethnography as a genre also gave her a new form of authority that was not dependent on the reestablishment of an imagined past or solely reliant on British colonial forms of documentation. Her writing was embedded in discourses on modernity, feminism, and nationalism as presented for an emerging Hindi-reading, female public. Through the women's periodical, the readership was already attuned to South-South connections from the contributions on various religious, feminist, and nationalist movements around the world. It has often been argued that the genre of the ethnography caused the very construction of the other. Nehru used the ethnography to unite women against both patriarchal and colonial domination, for she rightly recognized that the struggle against both was a common cause of women (and men).

\section{Acknowledgments}

I thank Balraj Persaud and the anonymous reviewers from the Journal of Asian Studies whose questions, criticism, and suggestions were invaluable for preparing the final version of this paper.

\section{List of References}

Aung SAn SuU KyI. 1990. Burma and India: Some Aspects of Intellectual Life under Colonialism. Shimla: Indian Institute of Advanced Study in association with Allied Publishers.

Ballantyne, Tony. 2003. "Rereading the Archive and Opening up the Nation-State: Colonial Knowledge in South Asia (and Beyond)." In After the Imperial Turn: 
Thinking with and through the Nation, ed. Antoinette Burton, 102-21. Durham, N.C.: Duke University Press.

Bechert, Heinz. 1984. “'To Be a Burmese Is to Be a Buddhist”: Buddhism in Burma.” In The World of Buddhism: Buddhist Monks and Nuns in Society and Culture, eds. Heinz Bechert and Richard Gombrich, 147-58. London: Thames and Hudson.

Billington, Mary F. [1895] 1925. Women in India. London: Chapman and Hall. Blackburn, Anne. 2010. Locations of Buddhism: Colonialism and Modernity in Sri Lanka. Chicago: University of Chicago Press.

Burton, Antoinette M. 1990. "The White Woman's Burden: British Feminists and the Indian Woman." Women's Studies International Forum 13(4):295-308.

—. 1994. Burdens of History: British Feminists, Indian Women, and Imperial Culture, 1865-1915. Chapel Hill: University of North Carolina Press.

Buzard, James, and Joseph Childers. 1999. "Introduction: Victorian Ethnographies." Victorian Studies 41(3):351-53.

Chakrabarty, Dipesh. 2000. Provincializing Europe: Postcolonial Thought and Historical Difference. Princeton, N.J.: Princeton University Press.

Chaudhuri, Nupur. 2008. "Krishnobhabini Das's Englande Bangamohila: An Archive of Early Thoughts on Bengali Women's Nationalism and Feminism." Journal of Women's History 20(1):197-216.

Chaudhuri, Nupur, and Margaret Strobel. 1990. "Western Women and Imperialism: Introduction." Women's Studies International Forum 13(4):289-93.

Chit Hlaing, U. 2008. "Anthropological Communities of Interpretation for Burma: An Overview." Journal of Southeast Asian Studies 39(2):239-54.

Dalmia, Vasudha. 1997. The Nationalization of Hindu Traditions: Bharatendu Harischandra and Nineteenth-Century Banaras. Delhi: Oxford University Press.

__ 1998. "A Novel Moment in Hindi: Pariksha guru." In Narrative Strategies: Essays on South Asian Literature and Film, eds. Vasudha Dalmia and Theo Damsteegt, 169-84. Delhi: Oxford University Press.

Forbes, Geraldine. 1998. Women in Modern India (The New Cambridge History of India, IV.2). Delhi: Cambridge University Press.

Ghose, Indira. 1998. The Power of the Female Gaze: Women Travellers in Colonial India. Delhi: Oxford University Press.

Ghosh, Amitav. 2001. The Glass Palace. New York: Random House.

Gombrich, Richard. 1988. Theravāda Buddhism: A social History from Ancient Benares to Modern Colombo. London: Routledge.

Grewal, Inderpal. 1996. Home and Harem: Nation, Gender, Empire and the Culture of Travel. Durham, N.C.: Duke University Press.

Ikeya, Chie. 2005-06. “The 'Traditional' High Status of Women in Burma: A Historical Reconsideration." Journal of Burma Studies 10:51-81.

. 2006. "Gender, History and Modernity: Representing Women in TwentiethCentury Colonial Burma.” PhD diss., Cornell University.

—. 2008. "The Modern Burmese Woman and the Politics of Fashion in Colonial Burma." Journal of Asian Studies 67(4):1277-1308.

Jayawardena, Kumari. 1995. The White Woman's Other Burden: Western Women and South Asia during British Colonial Rule. New York: Routledge.

Lwyn, Tinzar. 1994. "Stories of Gender and Ethnicity: Discourses of Colonialism and Resistance in Burma.” Australian Journal of Anthropology 5(1\&2):60-85.

Maung Maung. 1980. From Sangha to Laity: Nationalist Movements of Burma, 19201940. New Delhi: South Asia Books. 
Metcalf, Thomas. 2008. Imperial Connections: India in the Indian Ocean Arena 1860 1920. Berkeley: University of California Press.

Nehru, Rameshwari. 1917a. “Stri Kartavya” [Women’s duty]. Stri Darpan 7:2-6.

—. 1917b. "Parda" [Purdah]. Stri Darpan 8:60-64, 109-13.

—. 1917c. "Stri Shiksha ki Avashyakta" [The importance of women’s education]. Stri Darpan 12:309-14.

1920a. "Barma ki Striyam” [Burmese women]. Stri Darpan 2:69-80.

_. 1920b. "Barma mem Vivah ki Bhinn Bhinn Ritiyam" [The different marriage rites in Burma]. Stri Darpan 3:125-30.

Nijhawan, Shobna. 2012a. Women and Girls in the Hindi Public Sphere: Periodical Literature in Colonial North India. Delhi: Oxford University Press.

— 2012b. "The Idea of Asia: The All-Asian Women's Conference (1931) and the Unification of Asia." Paper presented at Annual Conference of the Association for Asian Studies, Toronto, March 15-18.

Orsini, Francesca. 1999. "Domesticity and Beyond: Hindi Women's Journals in the Early Twentieth Century." South Asia Research 19:137-60.

— 2002. The Hindi Public Sphere, 1920-1940: Language and Literature in the Age of Nationalism. Delhi: Oxford University Press.

Paliwal, Oм Prakash. 1986. Rameshwari Nehru: Patriot and Internationalist. New Delhi: National Book Trust.

Paxton, Nancy. 1990. "Feminism under the Raj: Complicity and Resistance in the Writings of Flora Annie Steel and Annie Besant." Women's Studies International Forum 13(4):333-46.

Ramusack, Barbara N. 1990. "Cultural Missionaries, Maternal Imperialists, Feminist Allies: British Women Activists in India, 1865-1945.” Women's Studies International Forum 13(4):309-21.

Sen, Indrani, ed. 1990. Memsahib’s Writings: Colonial Narratives on Indian Women. Hyderabad: Orient Longman.

Sinha, Mrinalini. 2006. Specters of Mother India: The Global Restructuring of an Empire. Durham, N.C.: Duke University Press.

Tuson, Penelope, ed. 1995. The Queen's Daughters: An Anthology of Victorian Feminist Writings on India, 1857-1900. Berkshire, England: Ithaca Press.

Visweswaran, Kamala. 1994. Fictions of Feminist Ethnography. Minneapolis: University of Minnesota Press. 